\title{
Genç Karaçam (Pinus nigra Arn.) Fidanlarında İbre Kaybının Fidanın Morfolojik ve Anatomik Özelliklerine Etkisi
}

\author{
Seray ÖZDEN KELEŞ ${ }^{1 *}$ \\ ${ }^{1}$ Kastamonu Üniversitesi, Orman Fakültesi, Orman Mühendisliği Bölümü,37200, KASTAMONU
}

Öz

Literatürde çeşitli miktarlarda ibre eksiltme uygulamasının ağaç fidan halinde iken fidanın büyümesine etkisi çok az araştırılmıştır. Bu nedenle, bu çalışmanın amacı, karaçam (Pinus nigra Arn.) fidanlarında çeşitli miktarlarda ibre eksiltme uygulamasının fidanın morfolojik, anatomik ve odun yoğunluk özelliklerine etkisini belirlemektir. Fidanlarda, ibre eksiltme miktarlarının fidan özelliklerine etkisini belirleyebilmek amacıyla fidanların gövdelerinden 4 farklı miktarda ibre eksiltilmiştir: $\% 0, \% 25, \% 50$ ve $\% 75$. Her bir ibre eksiltme uygulaması için, fidanların morfolojik (gövde çapı, nodyum sayısı, öz yüzdesi, kabuk yüzdesi ve ksilem yüzdesi), anatomik (ortalama yıllık halka genişliği, birim alanda traheid sayısı, traheid uzunluğu, traheid genişliği, traheid lumen genişliği, traheid hücre duvarı kalınlığı, öz ışını sayısı, öz ışınlarının uzunlukları ve genişlikleri) ve odun yoğunluk değerleri analizleri ayrı ayrı yapılmıştır. Morfolojik test bulguları $\% 0$ ve $\% 25$ miktarda ibre kesilmiş olan fidanlarda gövde çapının diğer ibre eksiltme uygulamalarından daha fazla olduğunu göstermiştir. Fakat, diğer bir morfolojik özellik olan nodyum sayısı, farklı miktarda ibre kesme uygulama işlemleri arasında istatistiksel olarak önemli bir değişim göstermemiştir. Her bir fidanda, nodyum sayısı yaklaşık 4 olarak tespit edilmiştir. Fidanların odun yoğunluk değerleri sonuçlarına göre, \% 0 ve \% 25 miktarda ibre eksiltmelerinde fidanların yoğunluk değerleri $\% 50$ ve $\% 75$ miktarda ibre eksiltme uygulamalarından daha yüksek çıkmıştır. Anatomik analiz sonuçlarına göre, hiç ibre eksiltilmemiş olan fidanlarda (\%0) öz ışınları daha uzun ve daha geniş bulunmuştur, ayrıca birim alanda $\left(1 \mathrm{~mm}^{2}\right.$ alanda) traheid sayısı ve traheid uzunluğu diğer ibre eksiltme uygulamalarından daha yüksek değerler çıkarmıştır. \% 25 ibre eksiltme uygulamasında ise ilginç biçimde traheid hücrelerinin hücre zarı kalınlığı diğer ibre eksiltme uygulamalarından daha yüksek saptanmıştır.

Anahtar Kelimeler: Morfoloji, Odun Anatomisi, İbre eksiltme, Çam fidanları, Yoğunluk.

\section{Anatomical and Morphological Changes with Needle Removal Treatments on the Seedlings of Pinus nigra Arn. (Anatolian black pine)}

The effect of needle removal treatments on the morphology, anatomy and wood density was less studied in the literature. Therefore, this study aimed to investigate the effect of needle removal on the morphological, anatomical and wood density properties of the seedlings of Pinus nigra Arn. (Anatolian black pine). The needles of the seedlings were removed in four different amounts $(0 \%, 25 \%, 50 \%$, and $75 \%)$ to determine whether there is a relationship between the properties of seedlings and the needle removal treatments. The morphological (stem diameter, node numbers, pith percentage, bark percentage, xylem percentage), anatomical properties (average annual ring width, tracheid number per $\mathrm{mm}^{2}$, tracheid height/width, tracheid lumen width, tracheid wall thickness, ray number per $\mathrm{mm}^{2}$, ray height/width) and wood densities were individually determined for each treatment. The morphological results showed that stem diameter was greatest in $0 \%$ and $25 \%$ needle removal treatments than that of two treatments. Bark\% was also found to be higher in the $0 \%$ needle removal treatments than others. However, node numbers, pith\%, and xylem\% did not differ significantly between four removal treatments. The density results showed that the seedlings of $0 \%$ and $25 \%$ needle treatments were denser than $50 \%$ and $75 \%$ needle removal treatments. The results of the anatomical analysis also found surprising results between four treatments. Ray height/width, tracheid number per $\mathrm{mm}^{2}$ and tracheid length were significantly greater in the $0 \%$ removal of needles than that of three treatments. $25 \%$ needle removal treatment also showed larger tracheid area and tracheid wall thickness than that of three needle removal treatments.

Keywords: Morphology, Wood Anatomy, Needle removal, Pine seedling, Density.

\footnotetext{
*Sorumlu Yazar (Corresponding Author):

Seray Özden Keleș (Dr.); Kastamonu Üniversitesi, Orman Fakültesi, Orman

Mühendisliği Bölümü, 37200, Kastamonu-Türkiye. Tel: +90 (366) 2801778 E-mail: 


\section{Introduction}

The leaves are one of the important organs in the tree body due to their physiological and biochemical functions. The vital importance of leaves is to provide light interception, photosynthesis, transpiration, food storage, etc. The leaves found to be in two forms between angiosperms and gymnosperms: angiosperms (deciduous) are trees have flat- or broad-leaves and gymnosperms (conifers or evergreens) are trees have needle-shaped leaves. Those trees have different life strategies in the dry season to survive harsh weather. Although angiosperms shed their leaves in the autumn, gymnosperms keep their leaves year-round. This is because, angiosperms have greater needle surface area than gymnosperms and this could be a disadvantage in harsh and dry weather; that is when water is scarce particularly in dry seasons, angiosperms should need to limit transpiration to grow, and thus they drop their leaves to conserve water and energy during dry seasons. Broadleaves also capture more sunlight for photosynthesis and thus they need to hold more water during scarce conditions. However, gymnosperms have needle-shaped leaves which are a narrow and small surface area in which water can evaporate slowly and minimize water loss and they do not need to conserve more water. Therefore, the needles (leaves) of evergreen gymnosperms produce food all year-round. The leaves so have a complicated structural workshop to the trees. Much research, therefore, concentrated on the structure of leaves to understand their excellent adaptive strategies to the environmental conditions.

Little is known about the effect of needle removal on plant growth when the tree is in the seedling stage. A seedling is a very young plant that grows from a seed and a tree which is usually less than 1 inch in context to the diameter at breast height. Seedling is also often regarded as the first stage of the growth cycle of a tree. Seedlings are highly tender and susceptible in their early life stages because they are exposed both environmental stresses (e.g. gravity force, wind, snow, rain) and abiotic factors (e.g. salinity, drought, light) (Smith and Fretwell, 1974; Cuneo et al., 2010; Baskin et al., 1998). However, seedlings face a fundamental trade-off between growing well all the year and remaining alive to environmental conditions. Therefore, an understanding of seedling growth and adaptation plays an important role to develop more effective management and control strategies in different seedling species. Furthermore, stem morphology and anatomy in different growth stages could provide better understanding related to the effect of environmental conditions on stem growth. This is because, the morphological characteristics such as stem diameter stem height, leaf phyllotaxy, and node numbers are highly influenced by the environmental factors. In addition, anatomical properties (cell number, cell dimensions, cell area, cell wall thickness, etc.) are directly correlated with the environments. Plants grow in two ways which are growing in length (known as primary growth) and growth in thickness (known as secondary growth) (Haberlandt, 1928; Thomas, 2000). Primary growth takes place in the apical meristems at the shoot tips. During height growth, nodes and internodes occur which are important structural parts in plants. The internode is the region between two nodes in stems and is responsible for the elongation. Nodes are the attachment points of the leaf and lateral buds to the stem (Zimmermann and Sperry, 1983; Salleo and LoGullo, 1986; LoGullo et al., 1995; Tyree and Zimmermann, 2002). Previous studies have shown that nodes are important structural elements in plants because they provide stem both hydraulic conductivity and flexibility (Zimmermann and Sperry, 1983; Salleo and Lo Gullo, 1986; Lo Gullo et al., 1995; Tyree and Zimmermann, 2002; Bergman et al., 2009; Caringella et al., 2014; Özden and Ennos, 2018). Anatomically, cell properties are also affected by environmental and ecological factors.

However, very little is known about how the amount of needles influences the morphological, anatomical and wood density properties when trees are at the seedling stage. The aim of this study, therefore, was to determine the effect of different needle removal treatments on the morphological, anatomical and wood density properties of Pinus nigra Arn. (Anatolian black pine) seedlings. The seedlings were subjected to four different needle removal treatments: $0 \%, 25 \%, 50 \%$ and $75 \%$ removal of the existing needles/leaves. The morphological properties (stem diameter, node numbers, pith\%, bark\%, and xylem\%), anatomical (average annual ring width, tracheid number per $\mathrm{mm}^{2}$, tracheid height/width, tracheid lumen width, tracheid wall thickness, ray number per $\mathrm{mm}^{2}$, ray height/width) and wood density were determined in each needle removal treatments.

\section{Material and Method}

\subsection{Site description}

The Pinus nigra Arn. (Anatolian black pine) seedlings were taken on the main campus of Kastamonu University, Kastamonu, Turkey. The experimental plots were located at an altitude of 700 to $800 \mathrm{~m}$ above sea level. The total annual rainfall at the site was approximately $580 \mathrm{~mm}$ and the annual mean temperature was $9.7^{\circ} \mathrm{C}$. 


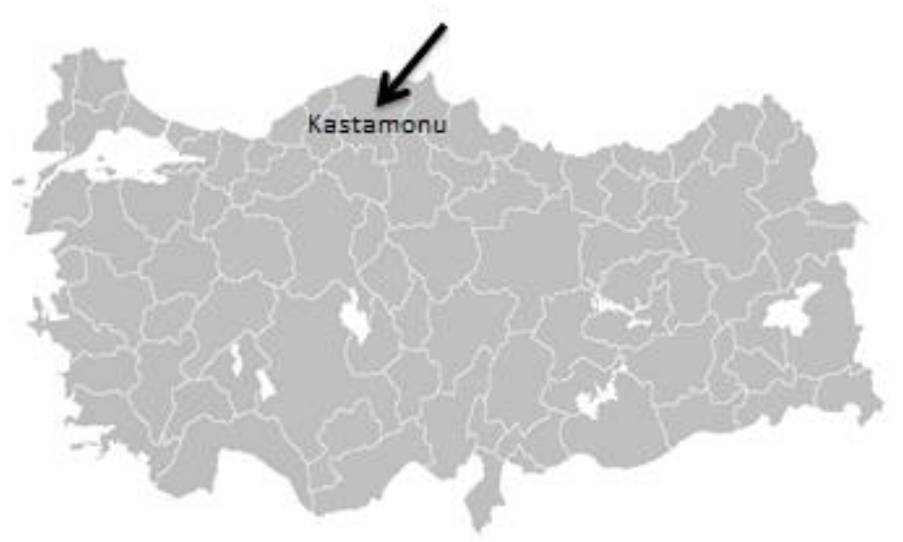

Figure 1. Location of the sampling area.

\subsection{Plant material}

Pinus nigra Arn. (Anatolian black pine) seedlings were used for the study. Anatolian black pine was chosen as a raw material because it is one of the main native and economically important tree species for Turkish forestry. It is also one of the commonly used tree species in afforestation studies. Black pine tree species cover almost 4.2- 4.7 million ha which is $19-20 \%$ of the total forest land in Turkey (Fig. 2).

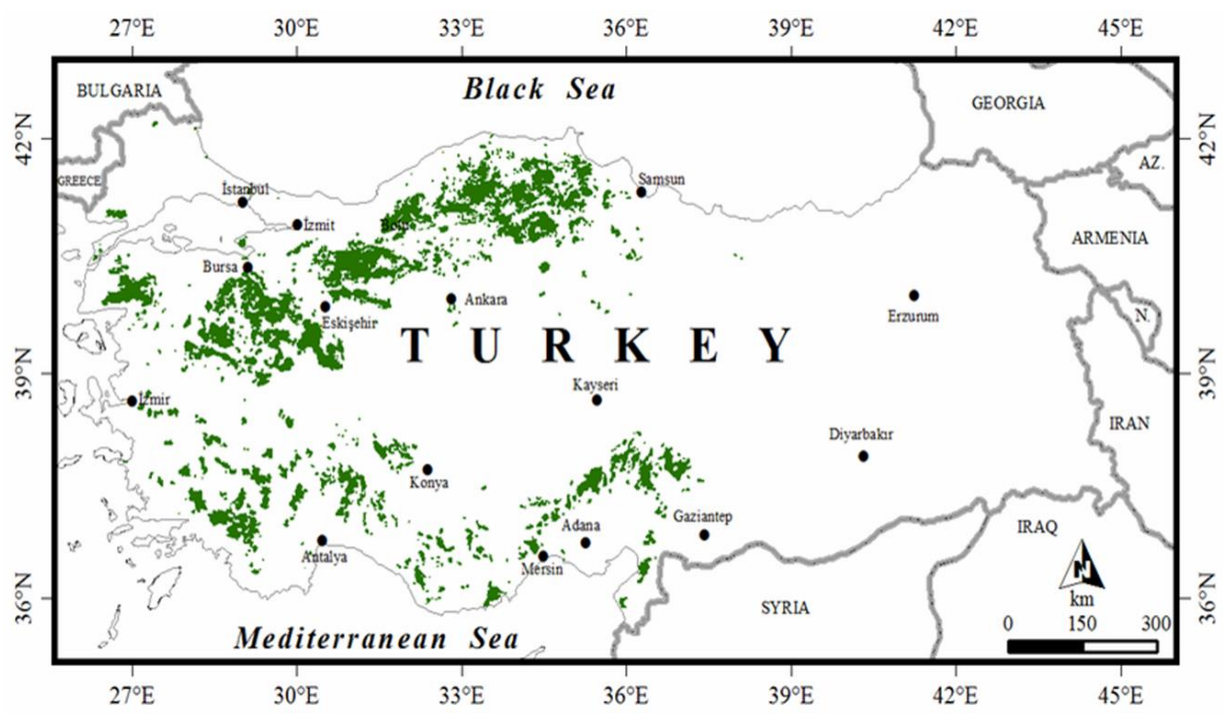

Figure 2. Distribution of Anatolian black pine in Turkey (Atalay and Efe, 2012).

A total of 60 seedlings of Anatolian black pine was obtained from the nursery of Daday Forest Planning Directorate, Kastamonu, Turkey. Seedlings were three-year-old and were randomly selected. Seedlings were $18-\mathrm{cm}$ deep-plug containerized seedlings with a rooting volume of $450 \mathrm{~cm}^{3}(5 \times 5 \times 18 \mathrm{~cm})$. To determine the effect of needle removal on the morphological, anatomical and wood density properties, the species were randomly assigned to one of the four treatments; $0 \%, 25 \%, 50 \%$ and $75 \%$ removal of the existing needles. Therefore, 15 samples were used for each treatment. Needle removal was conducted beginning from the stem base towards the shoot tip. $0 \%$ treatment means that no needles were removed from the stem and $50 \%$ treatment means half of the needles were removed from the stem. The samples were observed in the 1-year period. The samples treatments were begun in vegetation season (March) until the next growth season (next March - in a 1year period).

\subsection{Morphological and Anatomical data acquisition}

To characterize the effect of needle removal treatments on the stem properties, the seedlings were uprooted when they were at four-years-old. Some morphological parameters were determined such as stem diameter, node numbers, pith percentage, bark percentage and xylem percentage per each stem. The diameter of the stem was 
measured using a digital caliper (in $\mathrm{mm})$ for each treatment $(0 \%, 25 \%, 50 \%$, and $75 \%$ needle removals). The diameters were measured over bark, at above the ground level. The cross-sections of stems were nearly circular, so the diameters were taken from two sides of the main stem which are in the plane perpendicular and the plane parallel to the main stem (e.g. diameters were measured from horizontal and vertical planes of the stem). Then the average diameter was taken. The nodes were counted along with the stem height, the number per height was recorded for each removal treatments. The area calculations of pith, bark, and xylem were done based on the assumption that stems of seedlings have a circular transverse geometry. The average ring width was also measured for each removal treatment. The taper mode for each treatment was also calculated. The taper mode was measured based on the difference in diameter from stem base to tip.

For anatomical measurements, the stems of seedlings were cut into small wood sticks (approximately $1 \mathrm{~cm}$ in height). The small wood samples were boiled in water then were exposed to distilled water, glycerol and ethanol. Softened specimens were then cut into thin slices using sliding microtome. The specimens were sectioned in transverse and tangential sections to measure tracheid number per $\mathrm{mm}^{2}$, tracheid length/width, tracheid lumen width, tracheid wall thickness, ray numbers per $\mathrm{mm}^{2}$ and ray height/width. Franklin's maceration method (1945) was used to determine tracheid properties. Before the maceration, wood sticks were cut into strips (around 1x10 $\mathrm{mm}$ ) then Franklin's solution ( equal parts of hydrogen peroxide and glacial acetic acid 1:1 (v/v) were put into the glass beaker. Each strip individually was immersed in the prepared solution and kept in $90{ }^{\circ} \mathrm{C}$ distilled water for six to seven hours until the strip was delignified (Franklin, 1945; Makinen and Hynynen, 2014). Delignified sample was then shaken in distilled water in glass baker using a laboratory blender to separate tracheids from the strip gently. For microscopic analysis and observations, the tracheid suspension was then stained with safranin. The tracheid cell properties and annual ring width were measured in the transverse section (Fig.4a,b), ray number per $\mathrm{mm}^{2}$ and ray size (height and width) were determined in the tangential section (Fig.4c). 25 measurements were performed for each cell anatomical characterization. Leica DM750 (light microscope) was used to characterize the anatomical properties. The cell sizes and numbers were measured using a LAS EZ Image Analysis Software.

\subsection{Wood density measurement}

The seedlings were uprooted then store in a cold room at $4{ }^{\circ} \mathrm{C}$ to keep the specimens in green condition until the determination of wood density. To measure the wood density of each species, $3 \mathrm{~cm}$ circular-shaped specimens were cut from stems. To provide $100 \%$ moisture content, the green small pieces were held in water in airtight containers for 2 or 3 days until. The green volume of small pieces was weighed periodically to ensure specimens were fully hydrated. Then the water displacement method was used to determine the green volume of each sample. The small specimens were submerged in a beaker of water using a needle placed on an electronic weighing balance that gave a mass of water displacement. After volume measurements, the specimens were ovendried at $103^{\circ} \mathrm{C}$ until dry then their weight measured. Periodically again, dry mass of wood was weighed until constant weight gained (Barnett and Jeronimidis, 2003). To determine wood densities for each seedling stem, the dry mass of wood is divided by its fresh volume

$$
\text { Density }=\frac{\text { oven dry weight }}{\text { fresh volume }}
$$

\section{Results}

Needles were removed in four different treatments $(0 \% .25 \%, 50 \%$, and $75 \%)$. Each needle removal treatment showed different morphological, anatomical and wood density patterns in their stems.

\subsection{Morphological properties}

Stem diameter varied between average $6.9 \mathrm{~mm}$ to $8.1 \mathrm{~mm}$ depending on the amount of needle removals. $0 \%$ and $25 \%$ needle removals showed the greatest diameter in their stems than $75 \%$ and $50 \%$ needle removals, respectively. A one-way ANOVA results indicated diameter differed significantly between four needle removal treatments $\left(\mathrm{F}_{3,56}=4.991 p<0.05\right)$. The results of Post hoc tests also indicated $0 \%$ and $25 \%$ needle removals had significantly thicker stems than $75 \%$ and $50 \%$ needle removals. Interestingly, $75 \%$ needle removal treatment showed greater stem diameters than $50 \%$ needle removal treatment (Fig. 3). 


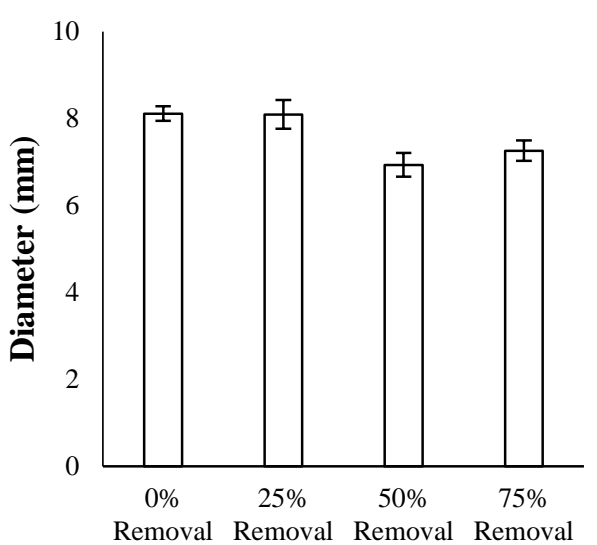

Needle Removal Amount

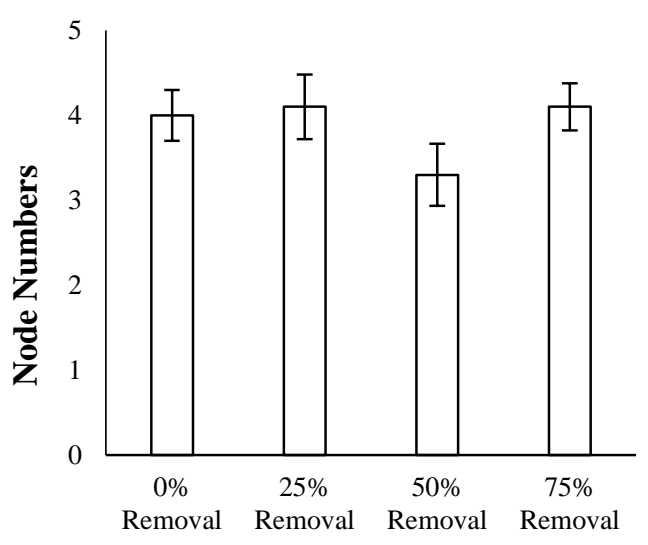

Needle Removal Amount

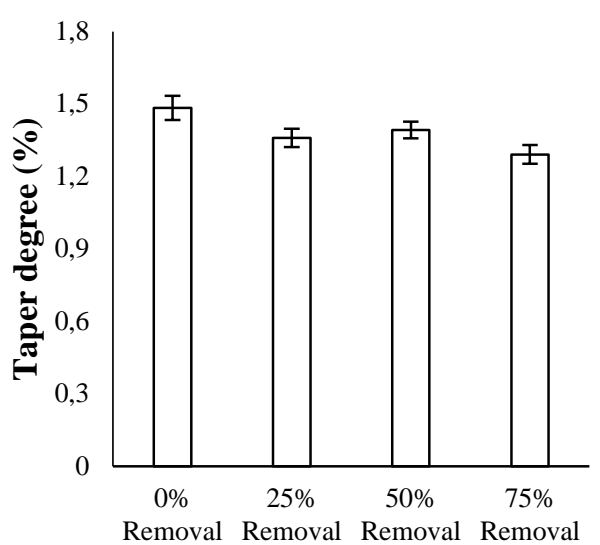

Needle Removal Amount

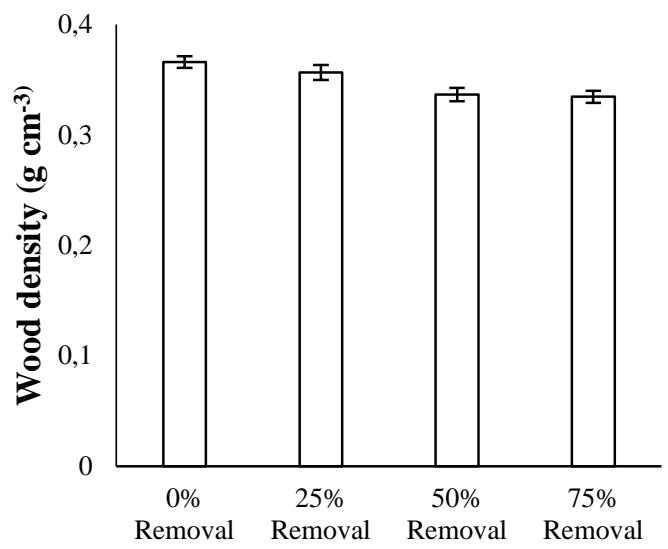

Needle Removal Amount

Figure 3. Mean diameters, taper degree, node numbers and wood density of seedlings in four needle removal treatments. $0 \%$ needle removal $(n=15), 25 \%$ needle removal $(n=15), 50 \%$ needle removal $(n=15)$ and $75 \%$ needle removal $(n=15)$. Error bars represent the standard error.

Each needle removal treatment showed different taper degree in their stems. The taper degree was greater in the $0 \%$ needle removal treatments than that of three treatments. The taper degree was 1.4 for $0 \%$ needle removal, 1.3 for $25 \%$ needle removal, 1.3 for $50 \%$ needle removal, and 1.2 for $75 \%$ needle removal. One-way ANOVA results found significant differences in diameter between four treatments $\left(\mathrm{F}_{3,56}=3.585 p<0.05\right)$ (Fig. 3). The degree of taper was significantly higher in $0 \%$ needle removals than that of three treatments. It is known that the high degree of taper is not a required property for stem structure since taper is closely linked with the plant growth (West et al. 1999). The stem of a plant is thicker at the base (near the root) and thinner at the tip (apex point). This is the growth strategy of a plant to make stem stronger because when the trees become taller the height and mass of trees should be balanced so the diameter should be higher at the base. The taper degree thus should be relatively lower to make stem stronger to environmental loads and trees' weight.

Node numbers were characterized for each needle removals. $25 \%$ and $75 \%$ needle removals showed 1.2 times greater node numbers than $0 \%$ and $50 \%$ needle removals. However, one-way ANOVA did not find a statistically significant difference in node numbers between four needle removal treatments $\left(\mathrm{F}_{3,56}=1.346 p>0.05\right)$. The node numbers varied between on average 3 to 4 along the length of the stem (Fig. 3).

Each needle removal treatment also showed different pith\%, bark\%, and xylem\% in their seedlings depending on the needle removal amount. Pith\% were on average 3.7\% for $0 \%$ needle removal treatment, $4.3 \%$ for $25 \%$ needle removal treatment, $3.2 \%$ for $50 \%$ needle removal treatment and $3.7 \%$ for $75 \%$ needle removal treatment (Table 1). One-way ANOVA results showed that pith\% did not differ significantly between four treatments $(p>0.05)$. Bark\% was greatest in the $0 \%$ needle removal treatment than that of three treatments and bark\% was lowest in the $75 \%$ needle removal treatment. Surprisingly, $75 \%$ needle removal treatment had higher xylem\% (on average $87.8 \%)$ than the other treatments. However, one-way ANOVA did not find a significant difference in xylem\% between four treatments $(p>0.05)$ (Table 1). 


\subsection{Anatomical properties}

Anatomical parameters showed different patterns between four needle removal treatments (Table 1). Annual ring widths were measured in each seedling for each needle removal treatment. The average ring width was greatest in $0 \%$ needle removal treatment than that of three removal treatments. The seedlings of $0 \%$ needle removal treatment had on average $0.73 \mathrm{~mm}$ ring width. However, one-way ANOVA found no significant difference in average ring widths between four treatments $(p>0.05)$.
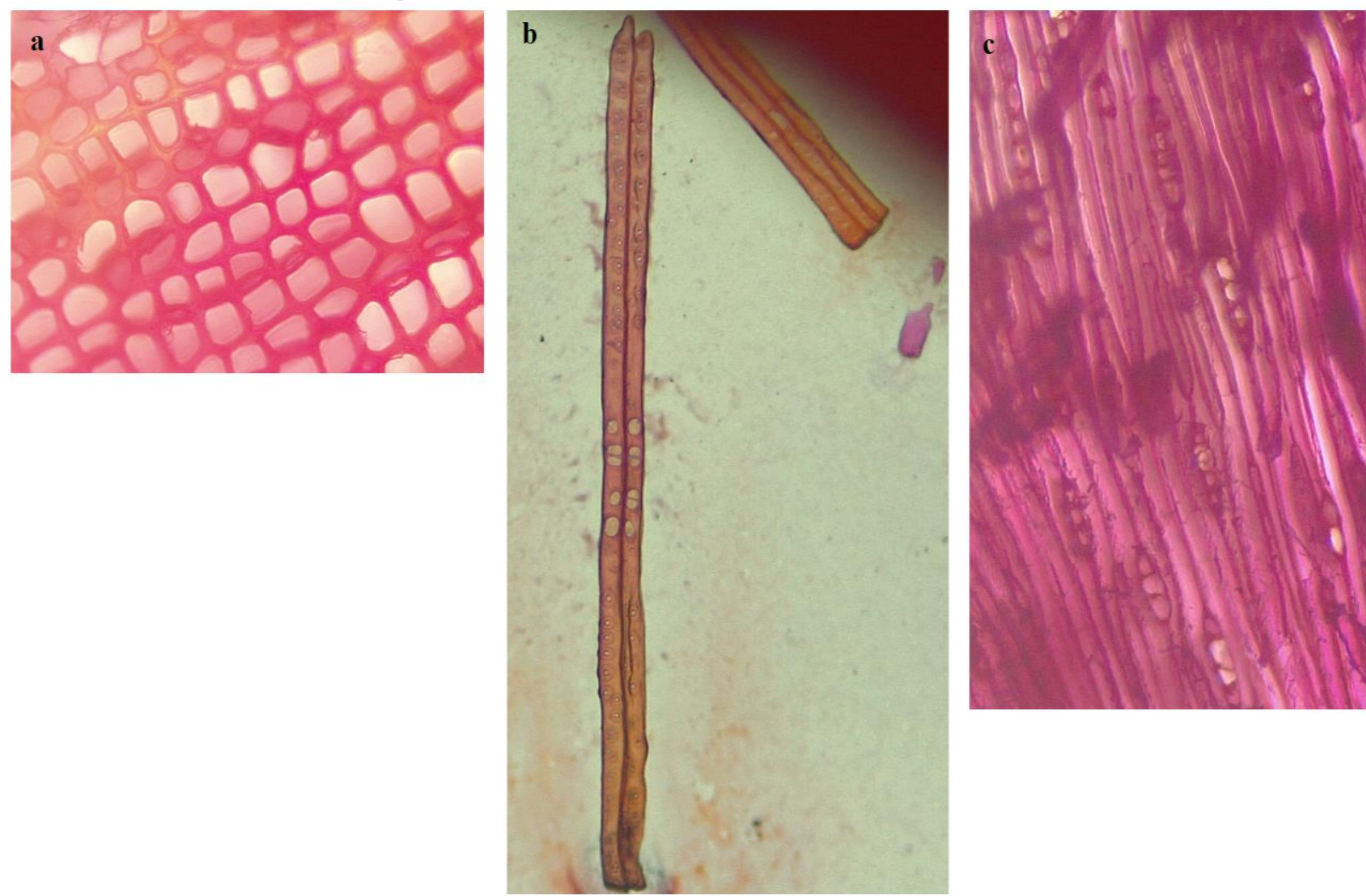

Figure 4. Showing (a) Tracheids in transverse section, (b) Delignified tracheids, (c) Rays in tangential section.

Microscopic characteristics: rays were found commonly uniseriate and height up between a minimum of two and a maximum of eight cells in length (Fig.4c). Ray number (per $\mathrm{mm}^{2}$ ) was found to be significantly higher in the $75 \%$ and $50 \%$ needle removal treatments respectively than $0 \%$ and $25 \%$ needle removals $(p<0.05)$. The number of rays was on average 18 in the $75 \%$ needle removal, 15 in the $50 \%$ needle removal, 12 in the $0 \%$ and $25 \%$ needle removals. The anatomical analysis also showed $0 \%$ needle removal had significantly greater height and width of ray values than $25 \%, 50 \%$, and $75 \%$ needle removal treatments. The average height of rays was $339.5 \mu \mathrm{m}$ and the average width of rays was $90.1 \mu \mathrm{m}$ in the $0 \%$ needle removal treatment. One-way ANOVA results also indicated there were significant differences in ray height and width between four treatments $(p>0.05)$ (Table 1). One-way ANOVA found significant differences in tracheid number and tracheid length between four needle removal treatments $(p<0.05) .0 \%$ needle removal treatment showed greater tracheid number and tracheid length values than the other three treatments. The average tracheid numbers were on average 108 in the $0 \%$ needle removal, 92 in the $25 \%$ needle removal, 70 in the $50 \%$ needle removal and 91 in the $75 \%$ needle removal. However, no significant differences were found in tracheid numbers between $25 \%, 50 \%$ and $75 \%$ needle removal treatments $(p$ $>0.05$ ). The average tracheid lengths varied between on average $1122.8 \mu \mathrm{m}$ (for $75 \%$ needle removal) and 1431.8 $\mu \mathrm{m}$ (for $0 \%$ needle removal). Interestingly, tracheid width and tracheid lumen width were higher in the $50 \%$ needle removal treatment. However, one-way ANOVA results revealed that tracheid width values and tracheid lumen width values were not significantly different between four treatments $(p>0.05)$. Tracheid wall thickness values also differed significantly between four needle removal treatments. $25 \%$ and $50 \%$ needle removal treatments showed greater tracheid wall thickness than $75 \%$ and $0 \%$ needle removal treatments. Tracheid wall thickness was on average $3.58 \mu \mathrm{m}$ in the $25 \%$ needle removal treatment and $2.38 \mu \mathrm{m}$ in the $50 \%$ needle removal treatment. $0 \%$ needle removal treatment showed the lowest tracheid wall thickness values (on average $1.95 \mu \mathrm{m})$ (Table 1). 
Table 1. The difference in morphological and anatomical characteristics between four needle removal treatments $(0 \%, 25 \%, 50 \%$, and $75 \%)$. The numbers in parentheses are standard deviations. Different letters indicate significant differences $(p<0.05$; post-hoc TUKEY test).

\begin{tabular}{|c|c|c|c|c|}
\hline & \multicolumn{4}{|c|}{ Needle Removal Treatments } \\
\hline & $\mathbf{0 \%}$ & $25 \%$ & $\mathbf{5 0 \%}$ & $75 \%$ \\
\hline \multicolumn{5}{|l|}{$\begin{array}{l}\text { Morphological } \\
\text { Characteristics }\end{array}$} \\
\hline Pith\% & $\begin{array}{l}3.7 \\
(1.14) \mathbf{a}\end{array}$ & $\begin{array}{l}4.3 \\
(2.47) \mathbf{a}\end{array}$ & $\begin{array}{l}3.2 \\
(1.45) \mathbf{a}\end{array}$ & $\begin{array}{l}3.7 \\
(1.03) \mathbf{a}\end{array}$ \\
\hline Bark\% & $\begin{array}{l}14.1 \\
(4.60) \mathbf{a}\end{array}$ & $\begin{array}{l}10.6 \\
(5.78) \mathbf{a b}\end{array}$ & $\begin{array}{l}12.7 \\
(5.37) \mathbf{a b}\end{array}$ & $\begin{array}{l}8.3 \\
(3.86) \mathbf{b}\end{array}$ \\
\hline Xylem\% & $\begin{array}{l}82.2 \\
(6.02) \mathbf{a}\end{array}$ & $\begin{array}{l}85.1 \\
(9.37) \mathbf{a}\end{array}$ & $\begin{array}{l}84.1 \\
(8.94) \mathbf{a}\end{array}$ & $\begin{array}{l}87.8 \\
(4.77) \mathbf{a}\end{array}$ \\
\hline \multicolumn{5}{|l|}{$\begin{array}{l}\text { Anatomical } \\
\text { Characteristics }\end{array}$} \\
\hline Average ring width $(\mathrm{mm})$ & $\begin{array}{l}0.73 \\
(0.12) \mathbf{a}\end{array}$ & $\begin{array}{l}0.69 \\
(0.12) \mathbf{a}\end{array}$ & $\begin{array}{l}0.67 \\
(0.08) \mathbf{a}\end{array}$ & $\begin{array}{l}0.68 \\
(0.11) \mathbf{a}\end{array}$ \\
\hline Ray Number (per $\mathrm{mm}^{2}$ ) & $\begin{array}{l}12 \\
(0.90) \mathbf{a}\end{array}$ & $\begin{array}{l}12 \\
(1.82) \mathbf{a}\end{array}$ & $\begin{array}{l}15 \\
(2.75) \mathbf{b}\end{array}$ & $\begin{array}{l}18 \\
(3.83) \mathbf{b}\end{array}$ \\
\hline Ray Height $(\mu \mathrm{m})$ & $\begin{array}{l}339.5 \\
(169.2) \mathbf{a}\end{array}$ & $\begin{array}{l}163.9 \\
(72.8) \mathbf{b}\end{array}$ & $\begin{array}{l}161.2 \\
(53.1) \mathbf{b}\end{array}$ & $\begin{array}{l}160.6 \\
(53.1) \mathbf{b}\end{array}$ \\
\hline Ray Width $(\mu \mathrm{m})$ & $\begin{array}{l}90.1 \\
(44.5) \mathbf{a}\end{array}$ & $\begin{array}{l}24.5 \\
(6.83) \mathbf{b}\end{array}$ & $\begin{array}{l}30.4 \\
(5.65) \mathbf{b}\end{array}$ & $\begin{array}{l}26.8 \\
(6.49) \mathbf{b}\end{array}$ \\
\hline $\begin{array}{l}\text { Tracheid Number (per } \\
\mathrm{mm}^{2} \text { ) }\end{array}$ & $\begin{array}{l}108 \\
(5.88) \mathbf{a}\end{array}$ & $\begin{array}{l}92 \\
(6.98) \mathbf{b}\end{array}$ & $\begin{array}{l}70 \\
(5.24) \mathbf{b}\end{array}$ & $\begin{array}{l}91 \\
(7.64) \mathbf{b}\end{array}$ \\
\hline Tracheid Length $(\mu \mathrm{m})$ & $\begin{array}{l}1431.8 \\
(373.7) \mathbf{a}\end{array}$ & $\begin{array}{l}1308.5 \\
(291.7) \mathbf{a b}\end{array}$ & $\begin{array}{l}1231.5 \\
(283.9) \mathbf{a b}\end{array}$ & $\begin{array}{l}1122.8 \\
(379.3) \mathbf{b}\end{array}$ \\
\hline Tracheid Width $(\mu \mathrm{m})$ & $\begin{array}{l}29.2 \\
(8.61) \mathbf{a}\end{array}$ & $\begin{array}{l}27.8 \\
(8.37) \mathbf{a}\end{array}$ & $\begin{array}{l}31.1 \\
(8.89) \mathbf{a}\end{array}$ & $\begin{array}{l}27.4 \\
(5.95) \mathbf{a}\end{array}$ \\
\hline $\begin{array}{l}\text { Tracheid Lumen Width } \\
(\mu \mathrm{m})\end{array}$ & $\begin{array}{l}7.7 \\
(1.91) \mathbf{a}\end{array}$ & $\begin{array}{l}8.1 \\
(1.46) \mathbf{a}\end{array}$ & $\begin{array}{l}9.2 \\
(2.53) \mathbf{a}\end{array}$ & $\begin{array}{l}7.2 \\
(1.39) \mathbf{a}\end{array}$ \\
\hline $\begin{array}{l}\text { Tracheid Wall Thickness } \\
(\mu \mathrm{m})\end{array}$ & $\begin{array}{l}1.95 \\
(0.58) \mathbf{b}\end{array}$ & $\begin{array}{l}3.58 \\
(2.02) \mathbf{a}\end{array}$ & $\begin{array}{l}2.38 \\
(0.47) \mathbf{a b}\end{array}$ & $\begin{array}{l}2.16 \\
(0.49) \mathbf{b}\end{array}$ \\
\hline
\end{tabular}

\subsection{Wood density}

Density varied between on average 0.33 to $0.36 \mathrm{~g} \mathrm{~cm}^{-3}$ in different specimens of seedlings. $0 \%$ and $25 \%$ needle removal treatment showed almost 1.1 times greater density than that of two needle removals. One-way ANOVA results showed that density significantly differed between four needle removal treatments $\left(\mathrm{F}_{3,56}=6.163 p<0.05\right)$. A post-hoc TUKEY test also showed that $25 \%$ and $0 \%$ removal treatments were significantly denser than $50 \%$ and $75 \%$ needle removals $(p<0.05)$ (Figure 3 ).

\section{Discussion and Conclusion}

This study showed that there are differences in morphological, anatomical wood density properties of pine seedlings depending on needle removal treatments. The needle removal amount markedly influenced the 
morphological structure of stems. Stem diameter is one of the important ecological phenomena and morphological parameters in plants that shows how plants respond to environmental conditions (Westoby and Wright, 2003; Niklas and Spatz, 2004; Sun et al., 2006; Olson et al., 2009; Xiang et al., 2009a).

The stem diameter is generally related to the environmental loads such as wind load is one of the largest environmental loads and wind makes stems thicker and shorter (Telewski, 1990; Jaffe and Forbes, 1993; Anten et al., 2005). Therefore, the stem diameter is a good indicator to determine the response of plant structure to environmental loads. In this study, the stem diameter varied significantly depending on needle removal treatment that is $0 \%$ and $25 \%$ needle removals presented thicker stems and 50\% and $75 \%$ needle removals showed thinner stems. The differences in thickness could be due to environmental adaptations since each seedling can show a different survival strategy to withstand and live long. It is known that cambial growth and water content can markedly influence the stem diameter. Growth in plants occurs in two ways which are primary growth (increase in length) and secondary growth (increase in thickness) (Haberlandt, 1928). Secondary growth thus provides the thickening of the stem. Secondary growth is produced by the activity of the vascular cambium (Haberlandt, 1928; Murmanis, 1970) which takes place in stems and roots after primary growth ends. The growth in vascular cambium is responsible for the thickening of the stem (Fosket, 1994). In this study, 0\% and 25\% needle removal treatment could make better secondary growth than the other needle removals. In $0 \%$ and $25 \%$ needle removal treatments, it could be suggested that needle removal positively affected the thickness in diameter. In addition, it is well known that needles in Gymnospermae provide long-term photosynthetic activity in stem and so play a major role related to the growth of a plant. The photosynthetic activity could probably continue and stems grow in thickness very well in $0 \%$ and $25 \%$ needle removal treatments. Therefore, this study well agrees with previous studies. However, further research is needed to understand why needle removal had a positive influence in the thickening of the stem, particularly in $25 \%$ amount of needle removal. The node number is also a good indicator to determine the mechanical response of stems to environmental loads. Previous studies showed that a decrease in node numbers make stem stiffer, but less flexible (Caringella et al., 2014; Özden and Ennos, 2018).

In general, wood density is also one of the important parameters in plants to determine wood quality since higher density makes the wood stronger and stiffer (Ifju and Kennedy, 1962; Ashby et al., 1985; Smith and Chui, 1994; Özden and Ennos, 2014). Wood density is correlated with cell wall material because denser woods have thicker cell walls, which make wood stiffer and stronger. In this study, stems were significantly denser in $0 \%$ and $25 \%$ needle removal treatments than that of two removal treatments. However, there were conflicting findings in this study. Although the wood density was greater in $0 \%$ and $25 \%$ needle removals, the tracheid wall thickness was lowest in the $0 \%$ needle removal treatment. As expected, the tracheid wall thickness was greater in the $25 \%$ needle removal because the stem of $25 \%$ needle removal treatment was denser.

Anatomical results showed that average annual ring width, ray height, ray width, tracheid number, and tracheid length were greater in the $0 \%$ needle removal treatment than that of three treatments as expected. This can be due to the survival adaptation of stems to environments because needles are the main sources of stems to make photosynthesis. When the major amounts of needles remained in the stems, the growth activity of the stems could be better so the plant grows very well. Otherwise, when the major amounts of needles were removed, plant growth could slow down. Therefore, remain needles could provide a short growth period. However, there were different patterns between $50 \%$ and $75 \%$ needle removal treatments such that ray numbers and tracheid lumen widths were found to be greater in the $50 \%$ and $75 \%$ needle removals. However, further research should be undertaken to investigate why needle removal treatments showed different properties in seedling stems.

As a conclusion, this study investigated the influence of the amount of needle removals on the morphological, anatomical and mechanical properties of the seedlings of black pine. As a result, the growth of the plant was better in the $0 \%$ and $25 \%$ needle removals than $50 \%$ and $75 \%$ needle removals. It could be also suggested that $25 \%$ amount of the needle removals did not affect negatively the plant growth.

\section{References}

1. Atalay I, Efe R (2012). Ecological attributes and distribution of Anatolian black pine [Pinus nigra Arnold. subsp. pallasiana Lamb. Holmboe] in Turkey. J Environ Biol., 33:509-19.

2. Anten NPR, Casado-Garcia R, Nagashima H (2005). Effects of mechanical stress and plant density on mechanical characteristics, growth and lifetime reproduction of tobacco plants. American Naturalist, 166: $650-660$. 
3. Ashby MF, Easterling KE, Harrysson R, Maiti SK (1985). The fracture and toughness of woods. Proc. Roy. Soc. Lond., A398: 261-280.

4. Barnett J, Jeronimidis G. (2003). Wood Quality and Its Biological Basis. Blackwell, 226 pp.

5. Baskin CC, Baskin JM (1998). Seeds, Ecology, Biogeography, and Evolution of Dormancy and Germination. San Diego, CA: Academic Press.

6. Bergman BA, Ewers FW, Bobich E (2009). Effect of leaf nodes on the mechanical properties of stems. Botany and Mycology 2009 (abstract). http://2009.botan yconf erenc e.org/engin e/searc h/index .php? func=detai $1 \&$ aid $=134$.

7. Calvert JR, Farrar RA (1999). An Engineering Data Book. Palgrave, Basingstoke.

8. Caringella MA, Bergman BA, Stanfield RC, Ewers MM, Bobich EG, Ewers FW (2014). Effects of phyllotaxy on biomechanical properties of stems of Cercis occidentalis (Fabaceae). Am J Bot., 101: 206-210.

9. Cuneo P, Offord CA, Leishman MR (2010). Seed ecology of the invasive woody plant African Olive (Olea europaea subsp. Cuspidate): implications for management and restoration. Australian Journal of Botany, 58(5): 342-348.

10. Fosket DE (1994). Plant growth and development. San Diego, CA: Academic Press, Inc.

11. Franklin GL (1945). Preparation of thin sections of synthetic resins and woody resin composites and a new method for wood. Nature, 155, 3924-3951.

12. Haberlandt G (1928). Physiological plant anatomy. MacMillian and Co., London.

13. Ifju G, Kennedy RW (1962). Some variables affecting microtensile strength of Douglas-fir. Forest Prod. J., 12: 213-217.

14. Jaffe MJ, Forbes S (1993). Thigmomorphogenesis: the effect of mechanical perturbation on plants. Plant Growth Regulation, 12: 313-324.

15. LoGullo MA, Salleo SE, Piaceri C, Russo R (1995). Relations between vulnerability to xylem embolism and xylem conduit dimensions in young trees of Quercus cerris. Plant Cell Environ., 18: 661669.

16. Makinen H, Hynynen J (2014). Wood density and tracheid properties of Scots pine: responses to repeated fertilization and timing of the first commercial thinning. Forestry, 87: 437-444.

17. Murmanis L (1970). Locating the initial in the vascular cambium of Pinus strobus L. by electron microscoby. Wood Science and Technology, 4: 1-14.

18. Niklas KJ (1992). Plant biomechanics: an engineering approach to plant form and function. University of Chicago Press, Chicago, p 622.

19. Niklas KJ, Spatz HC (2004). Growth and hydraulic (not mechanical) constraints govern the scaling of tree height and mass. Proc. Natl. Acad. Sci. U.S.A. 101: 15661-15663.

20. Olson ME, Aguirrehernández R, Rosell JA (2009). Universal foliage-stem scaling across environments and species in dicot trees: plasticity, biomechanics and Corner's rules. Ecol. Lett., 12: 210-219.

21. Ozden S, Ennos AR (2014). Understanding the function of rays and wood density on transverse fracture behaviour of green wood in three species. J Agric. Sci. Technol., B4: 731-743.

22. Özden S, Ennos R (2018). The mechanics and morphology of branch and coppice stems in three temperate tree species. Trees, 32: 933-949.

23. Salleo S, LoGullo MA (1986). Xylem cavitation in nodes and internodes of whole Chorisia insignis $H$. B. et K. plants subjected to water stress: relations between xylem conduit size and cavitation. Ann. Bot., 58: 431-441.

24. Smith I, Chui YH (1994). Factors affecting mode I fracture energy of plantation-grown red pine. Wood Sci. Technol. 28:147-157

25. Smith CC, Fretwell SD (1974). The optimal balance between size and number of offspring. Am. Nat., 108: 499- 506.

26. Sun S, Jin D, Shi P (2006). The leaf size-twig size spectrum of temperate woody species along an altitudinal gradient: an invariant allometric scaling relationship. Ann. Bot., 97: 97-107.

27. Telewski FW (1990). Structure and function of flexure wood in Abies fraseri. Tree Physiology 5:113.

28. Thomas P (2000). Trees: their natural history. Cambridge University Press, Cambridge.

29. Tyree MT, Zimmermann MH (2002). Xylem structure and the ascent of sap, 2nd edn. Springer, Berlin, p 283.

30. Westoby M, Wright IJ (2003). The leaf size-twig size spectrum and its relationship to other important spectra of variation among species. Oecologia, 135: 621-628.

31. West GB, Brown JH, Enquist BJ (1999). A general model for the structure and allometry of plant vascular systems. Nature, 400: 664-667.

32. Xiang S, Liu YL (2009b). Stem architectural effect on leaf size, leaf number, and leaf mass fraction in plant twigs of woody species. Int. J. Plant Sci., 170: 999-1008. 
33. Xiang S, Wu N, Sun SC (2009a). Within-twig biomass allocation in subtropical evergreen broadleaved species along an altitudinal gradient: allometric scaling analysis. Trees, 23: 637-647.

34. Zimmermann MH, Sperry JS (1983). Anatomy of the palm Rhapis excelsa. IX. Xylem structure of the leaf insertion. J. Arnold Arbor., 64: 599-609. 